\title{
Status and Forms of Zinc in Acidic Soils of Imphal West District, Manipur (India)
}

\author{
Herojit Singh Athokpam*, Lalramdinpuia Ralte, Nandini Chongtham, \\ Naorem Brajendra Singh, K. Nandini Devi, N. Gopimohan Singh and P.T. Sharma \\ College of Agriculture, Central Agricultural University, Imphal-795004, India \\ *Corresponding author
}

\begin{tabular}{|l|}
\hline K e y w o r d s \\
Zinc, Paddy fields, \\
Acidic, Critical \\
limit, Clay, Pea
\end{tabular}

\section{Introduction}

Zinc is one of the important micronutrients essential for plants, animals and human health. It is needed in very small amount but from the nutritional point of view, it is indispensable like any other essential nutrients. Almost half of the soils in the world are deficient in zinc. Indian soils are generally low in zinc. The field scale $\mathrm{Zn}$ deficiency in rice in tarai soil
Twenty soil samples were collected from various paddy fields of Imphal west district, Manipur to evaluate status and forms of zinc in the soils. All the soil samples were acidic in nature with mean value of $\mathrm{pH} 5.52$. The mean electrical conductivity was $0.09 \mathrm{dSm}^{-1}$ and the mean organic carbon content was $10.82 \mathrm{~g} \mathrm{~kg}^{-1}$. The mean cation exchange capacity, available nitrogen, available phosphorus and available potassium were 18.0 $\left[\mathrm{cmol}\left(\mathrm{p}^{+}\right) \mathrm{kg}^{-1}\right.$ ], $303.98 \mathrm{~kg} \mathrm{ha}^{-1}, 28.68 \mathrm{~kg} \mathrm{ha}^{-1}$ and $231.06 \mathrm{~kg} \mathrm{ha}^{-1}$, respectively. The mean value of DTPA extractable zinc was $0.91 \mathrm{mg} \mathrm{kg}^{-1}$. The DTPA extractable zinc show positive and significant correlation with EC, OC, CEC, available nitrogen, available potassium, silt and clay. A negative and significant correlation was observed with $\mathrm{pH}$, available phosphorus and sand. The distribution of zinc in the soil was in the order: WSEX-Zn $\left(0.40 \mathrm{mg} \mathrm{kg}^{-1}\right)<$ CRYOX-Zn $\left(1.35 \mathrm{mg} \mathrm{kg}^{-1}\right)<\operatorname{MnOX-Zn}\left(1.97 \mathrm{mgkg}^{-1}\right)<$ AMOX-Zn $\left(3.10 \mathrm{mg} \mathrm{kg}^{-1}\right)<$ OCX-Zn $\left(3.22 \mathrm{mg} \mathrm{kg}^{-1}\right)<\operatorname{Res}-\mathrm{Zn}\left(85.90 \mathrm{mg} \mathrm{kg}^{-1}\right)$. All the zinc fractions showed positive correlation with EC, OC, CEC, available nitrogen, available potassium, clay and negative correlation with $\mathrm{pH}$, available phosphorus and silt. The WSEX-Zn form showed the highest correlation with all the plant parameters and per cent contributions of this fraction was highest towards all the plant parameters. Application of zinc increases the total dry matter, zinc content in plant and zinc uptake by the plant. The critical limit of zinc in the soils was $0.69 \mathrm{mg} \mathrm{kg}^{-1}$ and the critical concentration of zinc in 50 days old pea plant tissue was 0.21 per cent. 
to increase productivity, correction of $\mathrm{Zn}$ deficiency is therefore, necessary which in turn requires the precise evaluation of available zinc in soil. It plays an important role in several plant metabolic processes; it activates enzymes and is involved in protein synthesis and carbohydrate, nucleic acid and lipid metabolism (Marschner, 1986; Pahlsson, 1989). However, like other heavy metals (Doncheva, 1998) when $\mathrm{Zn}$ is accumulated in excess in plant tissues, it causes alteration in vital growth processes such as photosynthesis and chlorophyll biosynthesis (Doncheva et al., 2001). An excess of $\mathrm{Zn}$ has been reported to have a negative effect on mineral nutrition (Chaoui et al., 1997).

Pea (Pisum sativum L.) is categorized as less sensitive to Zn deficiency (Alloway, 2008). However, $\mathrm{Zn}$ deficiency does occur in peas as $\mathrm{Zn}$ has many important roles in plant growth and a lack of $\mathrm{Zn}$ was linked to reduced seed formation (Bell and Dell, 2008). Zinc deficiency in human also appears to be a critical nutritional and health problem in the world. Challenge is being faced to increase seed/grain $\mathrm{Zn}$ concentration in crops to overcome widespread malnutrition especially in developing countries (Bouis and Welch, 2010). Thus, increasing $\mathrm{Zn}$ levels in seed could deliver more $\mathrm{Zn}$ to people who rely directly or indirectly on pea-derived food. Foliar analysis at a particular crop growth stage is widely used as a diagnostic guide for fertilization. Whole shoots or recently matured leaves at early flowering are the tissues usually recommended for analysis and seed usually is not a better index tissue for estimating the nutrient status of plants (Jones et al., 1991). Nevertheless, seed analyses have also been used for determining $\mathrm{Zn}$ supply to young plants (Rashid and Fox, 1992). Zinc concentration of seeds reflects differences among soils in their ability to supply $\mathrm{Zn}$ and the ability of plants to accumulate Zn (Rafique et al., 2011).
The availability of zinc to plants has been observed to vary with different zinc fractions. About five or less than 5 per cent of total zinc present in soil is available to plants at any given time. The form in which zinc is present in soil plays a crucial role in determining its availability to plants. Distribution of zinc forms in soils depends on the chemical and physical properties. The availability of soil zinc to plants is governed by a dynamic equilibrium among the different fractions of soil zinc whereas, relative availability of zinc in a soil is mainly governed by chemical changes in the soil solution, particularly the $\mathrm{pH}$. However, no systematic and exhaustive study had been made to delineate zinc status in acidic soils of Imphal west district, Manipur. Therefore, the present studied was undertaken to evaluate the zinc status and forms of the soil properties influencing it.

\section{Materials and Methods}

Twenty surface soil samples $(0-15 \mathrm{~cm})$ were collected from different locations of the cultivated fields of Imphal-West District, Manipur.

The air-dried soil samples were ground in wooden mortar and pestle and passed through $2 \mathrm{~mm}$ sieve. The mechanical analysis of the soils is determined by hydrometer method (Bouyoucos, 1951). These samples were analyzed for $\mathrm{pH}, \mathrm{EC}, \mathrm{P}_{2} \mathrm{O}_{5}$, and $\mathrm{K}_{2} \mathrm{O}$ using standard procedures as described by Jackson (1973), available N (Subbiah and Asija, 1956) and CEC as described by Borah et al., (1987). Organic carbon was determined by wet oxidation method of Walkley and Black (1934).

Available zinc was determined using Atomic Adsorption Spectrophotometer (ASS) as described by Lindsay and Norvell (1978). Different forms of zinc viz., water soluble plus exchangeable (WSEX), organically 
complexed (OCx), amorphous sesquioxide bound form (AMOX), crystalline sesquioxide bound form (CRYOX), and manganese oxide bound form (MnOX) were determined by sequential fractionation procedure outlined by Murthy (1982) modified by Mandal and Mandal (1986).

The pot culture experiment was carried out under net house to study the critical level of zinc in soils and 50 days old pea (cv. Rachna) during December, 2016-February, 2017. The harvested plants were washed in water. The samples were dried in an oven at $65^{\circ} \mathrm{C}$ for 48 hours, weighed and ground in stainless steel blender and digested in tri-acid mixture $\left(\mathrm{HNO}_{3}: \mathrm{HCLO}_{4}: \mathrm{H}_{2} \mathrm{SO}_{4}\right)$. Zinc content in the plants was determined by ASS. The critical soil and plant were determined by technique of Cate and Nelson (1965). Bray's per cent yield and uptake of pea was calculated as follows:

\section{Yield without fertilizer}

Bray's per cent yield =

Maximum yield in fertilizer treated pots

Uptake without fertilizer

Bray's per cent uptake $=$ $\mathrm{x} 100$

Maximum uptake in fertilizer treated pots

\section{Results and Discussion}

Results shows that soil $\mathrm{pH}$ values ranged from 5.02 to 6.51 (mean 5.52), EC varied from from $0.05 \mathrm{dSm}^{-1}$ to $0.15 \mathrm{dSm}^{-1}$ at $25^{\circ} \mathrm{C}$ (mean 0.09 $\left.\mathrm{dSm}^{-1}\right), \mathrm{CEC}$ from $11.9\left[\mathrm{cmol}\left(\mathrm{p}^{+}\right) \mathrm{kg}^{-1}\right]$ to 31.5 $\left[\operatorname{cmol}\left(\mathrm{p}^{+}\right) \mathrm{kg}^{-1}\right]$ (mean $18.0\left[\operatorname{cmol}\left(\mathrm{p}^{+}\right) \mathrm{kg}^{-1}\right]$ and organic carbon content ranged from 5.70 to $20.30 \mathrm{~g} \mathrm{~kg}^{-1}$ (mean $10.82 \mathrm{~g} \mathrm{~kg}^{-1}$ ). The available $\mathrm{N}, \mathrm{P}_{2} \mathrm{O}_{5}$, and $\mathrm{K}_{2} \mathrm{O}$ varied from $146.35 \mathrm{kgha}^{-1}$ to $405.59 \mathrm{kgha}^{-1}$ (mean $303.98 \mathrm{~kg} \mathrm{ha}^{-1}$ ), 21.57 $\mathrm{kgha}^{-1}$ to $43.42 \mathrm{kgha}^{-1}$ (mean $28.68 \mathrm{~kg} \mathrm{ha}^{-1}$ ) and $163.89 \mathrm{kgha}^{-1}$ to $298.41 \mathrm{kgha}^{-1}$ (mean $231.06 \mathrm{~kg} \mathrm{ha}^{-1}$ ), respectively. The soils were clay in textural class (Table 1).

\section{Total-Zn}

Total-Zn ranged from 71.33 to $131.33 \mathrm{mg} \mathrm{kg}^{-1}$ with an average of $95.93 \mathrm{mg} \mathrm{kg}^{-1}$. Total-Zn (Table 2) was positively and significantly correlated with EC $(\mathrm{r}=0.658 * *)$, organic carbon $(\mathrm{r}=0.702 * *)$, CEC $(\mathrm{r}=0.455 *)$ and negatively and significantly correlated with $\mathrm{pH}(\mathrm{r}=-0.499 *)$. Stevenson and Ardakani (1972) reported that the soluble Zn-organic complexes are mainly associated with amino, organic and fulvic acids while insoluble $\mathrm{Zn}$ organic complexes are derived from humic acids.

\section{Organically Complexed zinc (OCx-Zn)}

OCX-Zn ranged from 2.36 to $4.44 \mathrm{mg} \mathrm{kg}^{-1}$ and the mean value was $3.22 \mathrm{mg} \mathrm{kg}^{-1}$. OCx-Zn fraction was positively and significantly correlated with EC $(\mathrm{r}=0.638 * *)$, organic carbon $(\mathrm{r}=0.548 *), \quad \mathrm{CEC} \quad(\mathrm{r}=0.498 *)$, available potassium $(\mathrm{r}=0.675 * *)$, clay $(\mathrm{r}=0.516 *)$. It was negatively and significantly correlated with $\mathrm{pH}(\mathrm{r}=-0.554 *)$, available phosphorus $(\mathrm{r}=-0.643 * *)$.

The high content of OCX-Zn in the soils might be due to high organic carbon content. Prasad and Sakal (1988) and Pal et al., (1997) also suggested that the organic matter and clay provide exchange sites for the adsorption of $\mathrm{Zn}$ in the soils.

\section{Amorphous sesquioxide bound zinc (AMOX-Zn)}

AMOX-Zn ranged from 1.88 to $4.64 \mathrm{mg} \mathrm{kg}^{-1}$ and the mean value was $3.10 \mathrm{mg} \mathrm{kg}^{-1}$. AMOX$\mathrm{Zn}$ was positively and significantly correlated with EC $(\mathrm{r}=0.677 * *)$, organic carbon $(\mathrm{r}=0.447 *)$, CEC $(\mathrm{r}=0.460 *)$, available potassium $(\mathrm{r}=0.482 *)$. It was negatively and significantly correlated with $\mathrm{pH}(\mathrm{r}=-0.555 *)$, available phosphorus ( $\mathrm{r}=-0.633 * *)$. Similar finding was also reported by Das (2003). 
Int.J.Curr.Microbiol.App.Sci (2018) 7(4): 2349-2358

Table.1 Some physico-chemical properties of soil

\begin{tabular}{|c|c|c|c|c|c|c|c|c|c|c|c|}
\hline $\begin{array}{l}\text { Soil } \\
\text { No. }\end{array}$ & $\begin{array}{c}\mathrm{pH} \\
(\mathrm{mol} / \mathrm{lit})\end{array}$ & $\begin{array}{c}\mathrm{EC} \\
\left(\mathrm{dSm}^{-1}\right)\end{array}$ & $\begin{array}{l}\text { Org. C } \\
\left(\mathrm{g} \mathrm{kg}^{-1}\right)\end{array}$ & $\begin{array}{c}\text { Av. } N \\
\left(\mathrm{~kg} \mathrm{ha}^{-1}\right)\end{array}$ & $\begin{array}{c}\text { Av. P } \\
\left(\mathrm{kg} \mathrm{ha}^{-1}\right)\end{array}$ & $\begin{array}{c}\text { Av. K } \\
\left(\mathrm{kg} \mathrm{ha}^{-1}\right)\end{array}$ & $\begin{array}{c}\text { CEC } \\
{\left[\mathrm{cmol}\left(\mathbf{P}^{+}\right) \mathrm{kg}^{-1}\right]}\end{array}$ & $\begin{array}{l}\text { Sand } \\
(\%)\end{array}$ & $\begin{array}{l}\text { Silt } \\
(\%)\end{array}$ & $\begin{array}{l}\text { Clay } \\
(\%)\end{array}$ & $\begin{array}{c}\text { Textural } \\
\text { Class }\end{array}$ \\
\hline 1 & 5.54 & 0.07 & 9.60 & 317.78 & 32.29 & 227.81 & 19.30 & 22.10 & 32.50 & 45.40 & Clay \\
\hline 2 & 5.70 & 0.07 & 16.80 & 292.69 & 38.02 & 186.52 & 13.30 & 22.10 & 27.50 & 50.40 & Clay \\
\hline 3 & 5.24 & 0.08 & 9.90 & 380.50 & 29.04 & 239.68 & 16.00 & 11.20 & 22.50 & 66.30 & Clay \\
\hline 4 & 6.51 & 0.05 & 5.70 & 146.35 & 43.42 & 163.89 & 11.90 & 16.20 & 30.00 & 53.80 & Clay \\
\hline 5 & 5.46 & 0.10 & 7.50 & 246.70 & 28.07 & 237.55 & 14.70 & 10.50 & 30.00 & 59.50 & Clay \\
\hline 6 & 5.51 & 0.06 & 6.30 & 401.41 & 27.03 & 169.90 & 16.00 & 8.00 & 32.50 & 59.50 & Clay \\
\hline 7 & 5.57 & 0.08 & 6.40 & 175.62 & 26.76 & 201.04 & 20.10 & 18.70 & 20.00 & 61.30 & Clay \\
\hline 8 & 5.31 & 0.10 & 8.40 & 338.69 & 26.34 & 291.20 & 19.10 & 11.40 & 12.50 & 76.10 & Clay \\
\hline 9 & 5.48 & 0.09 & 7.20 & 171.43 & 27.03 & 184.65 & 13.90 & 22.80 & 17.50 & 59.70 & Clay \\
\hline 10 & 5.13 & 0.13 & 20.00 & 401.41 & 27.38 & 297.62 & 16.50 & 8.90 & 30.00 & 61.10 & Clay \\
\hline 11 & 5.21 & 0.12 & 16.80 & 255.06 & 26.00 & 286.27 & 27.90 & 8.90 & 20.00 & 71.10 & Clay \\
\hline 12 & 6.11 & 0.10 & 5.80 & 363.78 & 39.34 & 188.09 & 12.10 & 30.50 & 27.50 & 42.00 & Clay \\
\hline 13 & 5.83 & 0.09 & 11.00 & 359.59 & 29.66 & 197.72 & 16.70 & 26.90 & 10.00 & 63.10 & Clay \\
\hline 14 & 5.37 & 0.05 & 10.40 & 397.23 & 26.34 & 165.27 & 14.70 & 25.30 & 17.50 & 57.20 & Clay \\
\hline 15 & 5.45 & 0.08 & 16.80 & 271.79 & 25.37 & 204.51 & 22.70 & 25.50 & 25.00 & 49.50 & Clay \\
\hline 16 & 5.27 & 0.09 & 9.60 & 334.51 & 24.06 & 242.59 & 14.30 & 14.80 & 32.50 & 52.70 & Clay \\
\hline 17 & 6.13 & 0.09 & 9.20 & 284.33 & 25.86 & 278.77 & 19.50 & 9.80 & 32.50 & 57.70 & Clay \\
\hline 18 & 5.37 & 0.07 & 10.60 & 351.23 & 24.61 & 269.58 & 14.80 & 17.30 & 35.00 & 47.70 & Clay \\
\hline 19 & 5.27 & 0.08 & 8.10 & 183.98 & 25.51 & 290.19 & 25.70 & 22.80 & 20.00 & 57.20 & Clay \\
\hline 20 & 5.02 & 0.15 & 20.30 & 405.59 & 21.57 & 298.41 & 31.50 & 9.80 & 20.00 & 70.20 & Clay \\
\hline Mean & 5.52 & 0.09 & 10.82 & 303.98 & 28.68 & 231.06 & 18.00 & 17.20 & 24.80 & 58.10 & \\
\hline
\end{tabular}


Table.2 Amount of different zinc fractions $\left(\mathrm{mg} \mathrm{kg}^{-1}\right)$ in soils

\begin{tabular}{|c|c|c|c|c|c|c|c|c|}
\hline \multirow{2}{*}{$\begin{array}{c}\text { Soil } \\
\text { Samples }\end{array}$} & \multirow{2}{*}{$\begin{array}{c}\text { DTPA } \\
\text { extractant } \\
\text { Available Zn }\end{array}$} & \multicolumn{7}{|c|}{ Zinc fractions } \\
\hline & & WSEX-Zn & OCX-Zn & $\begin{array}{c}\text { AMOX- } \\
\text { Zn }\end{array}$ & CRYOX-Zn & $\mathrm{MnOX}-\mathrm{Zn}$ & Res-Zn & Total-Zn \\
\hline 1 & 1.06 & 0.68 & 2.84 & 2.40 & 1.33 & 2.65 & 74.76 & 84.67 \\
\hline 2 & 0.66 & 0.36 & 2.67 & 1.95 & 1.53 & 2.38 & 102.44 & 111.33 \\
\hline 3 & 1.08 & 0.33 & 3.16 & 2.53 & 1.33 & 1.70 & 72.28 & 81.33 \\
\hline 4 & 0.57 & 0.11 & 2.36 & 1.88 & 0.46 & 0.65 & 65.88 & 71.33 \\
\hline 5 & 0.75 & 0.37 & 2.63 & 4.61 & 1.55 & 2.80 & 87.37 & 99.33 \\
\hline 6 & 1.14 & 0.40 & 2.83 & 3.35 & 0.79 & 2.26 & 85.71 & 95.33 \\
\hline 7 & 0.86 & 0.31 & 3.31 & 2.48 & 1.78 & 0.72 & 81.40 & 90.00 \\
\hline 8 & 0.83 & 0.29 & 3.65 & 3.13 & 1.81 & 0.85 & 83.60 & 93.33 \\
\hline 9 & 0.63 & 0.13 & 3.68 & 3.08 & 0.81 & 2.65 & 101.65 & 112.00 \\
\hline 10 & 1.38 & 0.64 & 4.24 & 3.83 & 1.90 & 3.02 & 105.71 & 119.33 \\
\hline 11 & 1.17 & 0.41 & 3.92 & 3.79 & 1.27 & 1.72 & 94.89 & 106.00 \\
\hline 12 & 0.59 & 0.28 & 2.43 & 2.76 & 1.27 & 1.80 & 76.79 & 85.33 \\
\hline 13 & 0.85 & 0.49 & 2.71 & 3.01 & 1.87 & 2.05 & 99.86 & 110.00 \\
\hline 14 & 0.76 & 0.39 & 3.12 & 2.77 & 1.59 & 1.60 & 76.52 & 86.00 \\
\hline 15 & 0.72 & 0.51 & 2.93 & 3.76 & 1.13 & 2.13 & 89.53 & 100.00 \\
\hline 16 & 1.09 & 0.16 & 2.96 & 3.19 & 1.23 & 2.40 & 70.73 & 80.67 \\
\hline 17 & 0.91 & 0.23 & 3.76 & 2.91 & 1.44 & 1.22 & 69.78 & 79.33 \\
\hline 18 & 0.83 & 0.32 & 3.97 & 3.27 & 1.10 & 0.77 & 76.57 & 86.00 \\
\hline 19 & 0.71 & 0.45 & 2.75 & 2.68 & 0.52 & 2.83 & 86.77 & 96.00 \\
\hline 20 & 1.68 & 1.14 & 4.44 & 4.64 & 2.21 & 3.23 & 115.67 & 131.33 \\
\hline Mean & 0.91 & 0.40 & 3.22 & 3.10 & 1.35 & 1.97 & 85.90 & 95.93 \\
\hline
\end{tabular}

$($ WSEX-Zn=Water soluble + Exchangeable zinc; OCx-Zn = Organically complexed zinc; AMOX-Zn = Amorphous sesquioxide bound zinc; CRYOX-Zn = Crystalline sesquioxide bound zinc; MnOX-Zn = Manganese oxide bound zinc; Res-Zn = Residual zinc; Total-Zn = Total zinc). 
Table.3 Simple correlation coefficient of different forms of zinc and soil physico-chemical properties

\begin{tabular}{|c|c|c|c|c|c|c|c|c|c|}
\hline & \multirow{2}{*}{$\begin{array}{c}\text { Soil } \\
\text { properties }\end{array}$} & \multirow{2}{*}{$\begin{array}{c}\text { DTPA extractant } \\
\text { Available Zn }\end{array}$} & \multicolumn{7}{|c|}{ Zinc fractions } \\
\hline & & & WSEX-Zn & OCx-Zn & AMOX-Zn & CRYOX-Zn & $\mathrm{MnOX}-\mathrm{Zn}$ & Res-Zn & Total Zn \\
\hline 1 & $\mathrm{pH}$ & $-0.599 * *$ & $-0.496 *$ & $-0.554 *$ & $-0.555 *$ & -0.334 & $-0.464 *$ & $-0.453 *$ & $-0.499 *$ \\
\hline 2 & $\mathrm{EC}$ & $0.633 * *$ & $0.542 *$ & $0.638 * *$ & $0.677 * *$ & $0.555^{* *}$ & 0.433 & $0.614 * *$ & $0.658 * *$ \\
\hline 4 & $\mathrm{CEC}$ & $0.561 * *$ & $0.668 * *$ & $0.498 *$ & $0.460 *$ & 0.248 & 0.261 & 0.424 & $0.455 *$ \\
\hline 5 & Av. N & $0.551 *$ & $0.457 *$ & 0.259 & 0.295 & $0.517 *$ & 0.208 & 0.143 & 0.187 \\
\hline 6 & Av. P & $-0.523 *$ & -0.341 & $-0.643 * *$ & $-0.633 * *$ & -0.300 & -0.225 & -0.266 & -0.322 \\
\hline 8 & Sand & $-0.637 * *$ & -0.137 & -0.113 & -0.021 & -0.322 & -0.038 & -0.399 & -0.373 \\
\hline 9 & Silt & 0.068 & -0.123 & -0.018 & -0.138 & -0.382 & -0.315 & -0.492 & -0.484 \\
\hline 10 & Clay & $0.462 *$ & 0.214 & $0.516 *$ & 0.376 & 0.404 & -0.022 & 0.382 & 0.396 \\
\hline
\end{tabular}

Table.4 Simple correlation coefficient among the different forms of zinc fractions

\begin{tabular}{|c|c|c|c|c|c|c|c|c|c|}
\hline & & DTPA-Zn & WSEX-Zn & OCx-Zn & AMOX-Zn & CRYOX-Zn & MnOX-Zn & Res-Zn & Total-Zn \\
\hline 1 & DTPA-Zn & 1 & $0.717 * *$ & $0.650 * *$ & $0.545 *$ & $0.502 *$ & 0.406 & 0.403 & $0.462 * *$ \\
\hline 2 & WSEX-Zn & & 1 & 0.398 & $0.513 *$ & $0.540 *$ & $0.572 * *$ & $0.609 * *$ & $0.650 * *$ \\
\hline 3 & $\mathrm{OCx}-\mathrm{Zn}$ & & & 1 & $0.500 *$ & $0.449 *$ & 0.050 & 0.428 & $0.472 *$ \\
\hline 4 & AMOX-Zn & & & & 1 & 0.384 & $0.461 *$ & $0.508 *$ & $0.569 * *$ \\
\hline 5 & CRYOX-Zn & & & & & 1 & 0.126 & 0.438 & $0.476 *$ \\
\hline 6 & $\mathrm{MnOX}-\mathrm{Zn}$ & & & & & & 1 & $0.617 * *$ & $0.644 * *$ \\
\hline 7 & Res-Zn & & & & & & & 1 & $0.996 * *$ \\
\hline 8 & Total-Zn & & & & & & & & 1 \\
\hline
\end{tabular}


Fig.1 Relationship between soil Zn and relative yield of pea

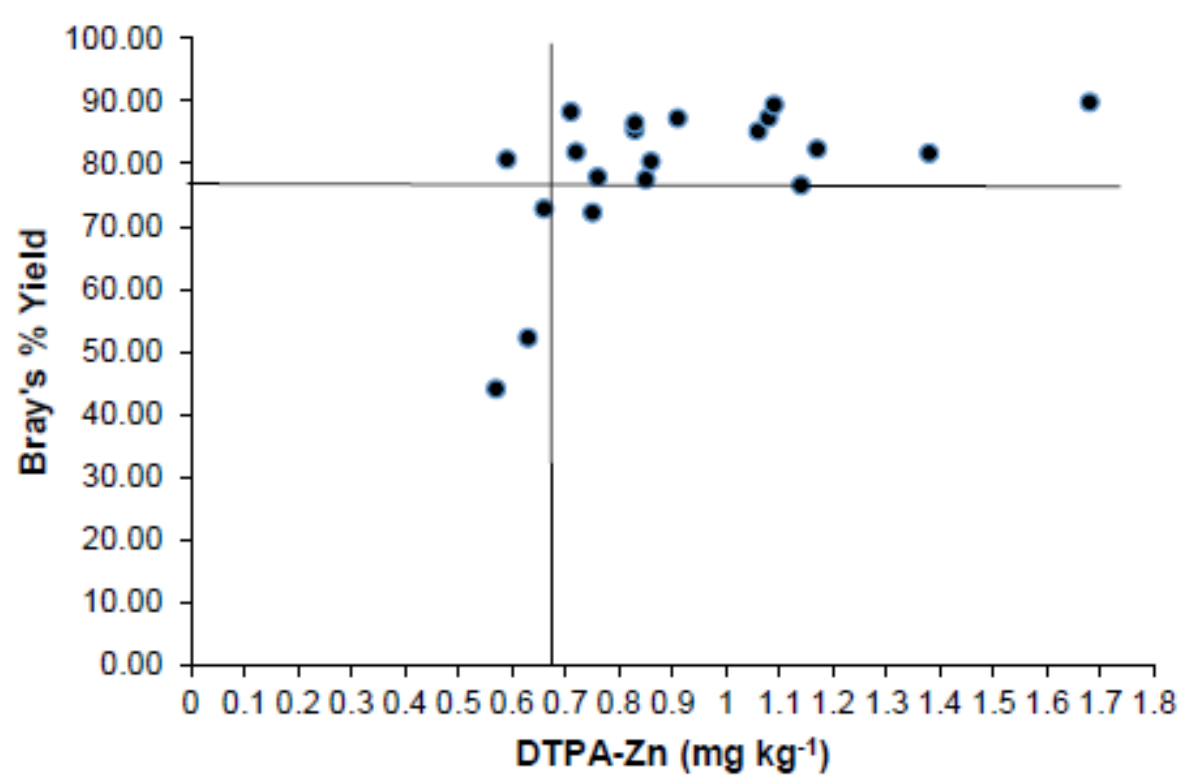

Fig.2 Relationship between the plant $\mathrm{Zn}$ concentration and relative yield of pea

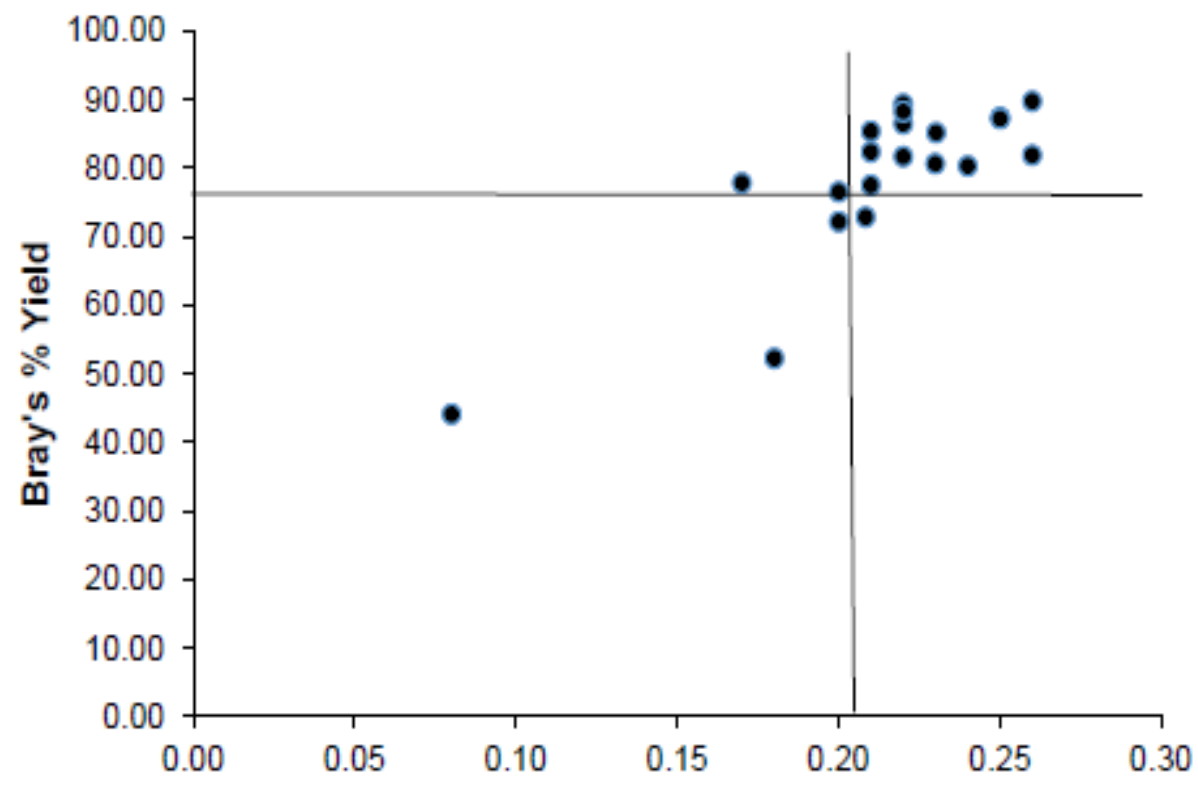

Crystalline sesquioxide bound zinc correlated with EC ( $\mathrm{r}=0.555 *)$, organic (CRYOX-Zn) carbon $(\mathrm{r}=0.501 *)$, available nitrogen $\left(\mathrm{r}=0.517^{*}\right)$ as $\mathrm{Zn}$ interacts with crystalline CRYOX-Zn ranged from 0.46 to $2.21 \mathrm{mg} \mathrm{kg}^{-1}$ iron oxide bound which was in line with the and the mean value was $1.35 \mathrm{mg} \mathrm{kg}^{-1}$. finding of Spalbar et al., (2017). CRYOX-Zn was positively and significantly 


\section{Manganese oxide bound zinc (MnOX-Zn)}

MnOX-Zn ranged from 0.65 to $3.23 \mathrm{mg} \mathrm{kg}^{-1}$ and mean value was $1.97 \mathrm{mg} \mathrm{kg}^{-1}$. It was negatively and significantly correlated with $\mathrm{pH} \quad(\mathrm{r}=-0.464 *)$. Higher the manganese content in the soils lowers the zinc content in the soils as the studied soils are acidic which might have content high amount of $\mathrm{Mn}$ as reported by many workers.

\section{Residual zinc (Res-Zn)}

Res-Zn ranged from 65.88 to $115.67 \mathrm{mg} \mathrm{kg}^{-1}$ and the mean value was $85.90 \mathrm{mg} \mathrm{kg}^{-1}$. Res$\mathrm{Zn}$ was positively and significantly correlated with EC $(\mathrm{r}=0.614 * *)$, organic carbon $(\mathrm{r}=0.678 * *)$. It was negatively and significantly correlated with $\mathrm{pH}(\mathrm{r}=-0.453 *)$.

Positive and significant correlation with organic carbon indicates that some portion of residual $\mathrm{Zn}$ is derived from resistant organic matter and Fe oxides (Singh et al., 1988). Residual Zn was the dominant fraction among all the fractions in the soils and is in agreement with the finding of Raja and Iyengar (1986).

\section{Correlation between various $\mathrm{Zn}$ fractions}

There is positive and significant correlation among different zinc fractions with varying degrees (Table 3). The highest significant correlation was found between Res- $\mathrm{Zn}$ and Total-Zn ( $\mathrm{r}=0.996 * *)$ and the least significant correlation was found between OCx-Zn and CRYOX-Zn $\quad(\mathrm{r}=0.449 *)$. Such close relationships between different forms suggested that they are more or less the same forms of $\mathrm{Zn}$ indicating the existence of dynamic equilibrium among different forms of $\mathrm{Zn}$ but relatively of different degree. Similar observations were also reported by Pal et al., (1997), Mandal et al., (1986) and Sharma et al., (1996) (Table 4).

\section{Critical level of $\mathbf{Z n}$}

According to the graphical procedure of Cate and Nelson (1965) the critical level of $\mathrm{Zn}$ in the soil is $0.69 \mathrm{mg} \mathrm{kg}^{-1}$ (Fig. 1) for demarcating the $\mathrm{Zn}$ responsive soils from non-responsive ones. The critical concentration of zinc in 50 days old pea plant tissue was 0.21 per cent (Fig. 2) using a scatter diagram partitioning the dimensional percentage yield versus $\mathrm{Zn}$ content in pea plants scatted into two groups. This finding is closely related with the findings by Singh et al., (1999), Sakal et al., (1984) and Kumari et al., (2013).

\section{References}

Alloway, B.J. 2008. Micronutrient deficiencies in global crop production. Springer, Dordrecht.

Bell, R.W. and Dell, B. 2008. Micronutrient for sustainable food, feed, fibre and bioenergy production. International Fertilizer Industries Association, Paris, France.

Borah, D.K., Bordoloi, P.K., Karmakar, R.M., Baruah, N.G. and Das, M. 1987. Practical Manual of Fundamental of Soil Science (Part-III), Jorhat, Assam.

Bouis, H.E. and Welch, R.M. 2010. Biofortification a sustainable agricultural strategy for reducing micronutrient malnutrition in the global south. Crop Science. 50:520-532.

Bouyoucos, G.J. 1951. Soil Science. 23: 319343.

Cate, R.B. and Nelson, L.A. 1965. Graphical procedure for critical limits of nutrients. Proceedings of Soil Science Society of America. 89: 658.

Chaoui, A., Mazhoudi, S., Ghorbal, M.H. and Elferjani, E. 1997. Cadmium and zinc induction of lipid peroxidation and effects on antioxidant enzyme activities 
in bean (Phase olus vulgaris L.). Plant Science. 127: 139-147.

Das, D.K. 2003. Micronutrients: their behavior in soils and plants. Kalyani Publishers, New Delhi.

Doncheva, S. 1998. Cropper induced alteration in structure and proliferation of root meristem cells. Journal of Plant Physiology. 153: 118-122.

Doncheva, S., Stoyanova, Z. and Velikova, V. 2001. The influence of succinate on zinc toxicity of pea plant. Journal of Plant Nutrition. 24: 789-806.

Jackson, M.L. 1973. Soil Chemical Analysis. Prentice Hall of India Pvt. Ltd., New Delhi.

Jones, J.B. Jr., Wolf, B. and Mills, H.A. 1991. Plant Analysis Handbook. Micro-Macro Publishing Inc. Athens, Georgia, USA.

Kumar, M., Jha, A.K., Hazarika, S., Verma, B. C., Choudhury, B.U., Ramesh, T. and Devi, M.H. 2016. Micronutrients (B, Zn, Mo) for improving crop production on acid soils of Northeast India. National Academy of Science Ltters. 39(2): 85-89.

Kumari, M., Yadav, K. and Nisha, K. 2013. Critical limits of zinc in soil and plants of maize in Diaraland soils of Bihar. Environment and Ecology. 31(2): 11071110.

Lindsay, W.L. and Norvell, W.A. 1978. Development of DTPA soil test for zinc, manganese and copper. Soil Science Society of American Journal. 42: 421-428.

Mandal, B., Halder, B.R. and Mandal, L.N. 1986. Distribution of different forms of zinc in some rice growing soils. Journal of the Indian Society of Soil Science. 35: 672-676.

Mandal, M.N. and Mandal, B. 1986. Zinc fractions in soils in relation to zinc nutrition of lowland rice. Soil Science. 142: 141-148.
Marschner, H. 1986. Mineral nutrition of higher plants. Academic Press, New York.

Murthy, A.S.P. 1982. Zinc fractions in wetland rice soils and their availability to rice. Soil Science. 133(3): 150-154.

Nene, Y.L. 1966. Symptoms, cause and control of khaira disease of paddy. Bulletin of Indian Phytophathological Society No.3: 97-101.

Pahlsson, A.M.B. 1989. Toxicity of heavy metals $(\mathrm{Zn}, \mathrm{Cu}, \mathrm{Cd}, \mathrm{Pb})$ to vascular plants. Water Air, Soil Pollution. 47: 287-319.

Pal, A.K., Das, P.R., Patnaik, S.K. and Mandal, B. 1997. Zinc fractions in some rice growing soils of Orissa. Journal of the Indian Society of Soil Science. 45: 734-738.

Prasad, R. and Sakal, R. 1988. Effect of soil properties on different chemical pools of zinc in calcareous soils. Journal of the Indian Society of Soil Science. 36(2): 246-251.

Rafique, E., Mahmood-ul-Hassan, M., Ishaq, M. and Khokhar, K.M. 2011. Determining the zinc requirement of onion by seed analysis. Journal of Plant Nutrition. 34: 492-503.

Rasid, A. and Fox, R.L. 1992. Evaluating internal zinc requirement of grain crops by seed analysis. Agronomy Journal. 84: 469-474.

Sakal, R., Singh, A.P., Singh, B.P. and Sinha, R.B. 1984. Assesment of some chemical extractants for available zinc in relation to response of rice to applied zinc in sub-Himalayan hill and forest soils. Plant and Soil. 79: 417-428.

Sharma, B.L., Bhadoria, A.K.S., Rathore, G.S. and Bapat, P.N. 1996. Evaluation of extractants for available zinc and its forms in vertisols of Madhya Pradesh. Journal of the Indian Society of Soil Science. 44: 701-704. 
Singh, A.K., Nongkynrih, P. and Khan, S.K. 1999. Critical limit of $\mathrm{Zn}$ deficiency for predicting response of rice soils of Meghalaya. Journal of the Indian Society of Soil Science.47: 567-569.

Singh, J.P., Karwassa, S.P. and Singh, M. 1988. Distribution and forms of copper, iron, manganese and zinc in calcareous soils of India, Soil Science. 146: 359366.

Spalbar, E., Mandal, A.K. and Rai, A.P. 2017. Distribution of zinc fractions and its association with soil properties in some rice-wheat growing soils of Jammu region, India. International Journal of
Current Microbiology Applied Sciences. 64(4): 711-721.

Stevenson, F.J. and Ardakani, M.S. 1972. In: Micronutrients in Agriculture. Pp. 79114. Soil Science Society of America Inc., Madison.

Subbiah, B.V. and Asija, G.L. 1956. A rapid procedure for estimation of available $\mathrm{N}$ in soils. Current Science. 25: 259-260.

Walkley, A. and Black, I.A. 1934. An examination of the Degtjareff method determining soil organic matter and a proposed modification of the chromic acid titration method. Soil Science. 34: 29-38.

\section{How to cite this article:}

Herojit Singh Athokpam, Lalramdinpuia Ralte, Nandini Chongtham, Naorem Brajendra Singh, K. Nandini Devi, N. Gopimohan Singh and Sharma, P.T. 2018. Status and Forms of Zinc in Acidic Soils of Imphal West District, Manipur (India). Int.J.Curr.Microbiol.App.Sci. 7(04): 2349-2358. doi: https://doi.org/10.20546/ijcmas.2018.704.269 